\title{
Analisis Kelayakan Pengembangan Usaha Rumah Makan Krebo Jantan
}

\author{
Gerry Anugrah Dwiputra* \\ Program Studi Teknik Industri, Fakultas Teknik, Universitas Serang Raya \\ Email: gerry.adp@gmail.com
}

\begin{abstract}
Abstrak -- Rumah Makan Krebo Jantan memiliki rencana untuk melakukan pengembangan usaha pada bidang makanan. Rumah Makan Krebo Jantan memiliki permasalahan tentang apakah rencana pengembangan usahanya dapat memberikan kelayakan bagi perkembangan perusahaan di masa mendatang. Tujuan penelitian ini adalah mengetahui kelayakan usaha pada rencana pengembangan bisnis makanan dengan batasan penelitian pada penilaian aspek pasar \& aspek keuangan. Obyek dalam wawancara dan kuesioner adalah pemilik usaha dan warga sekitar tempat usaha. Data pada aspek pasar dianalisa dengan menggunakan Metode Strengths, Weaknesses, Opportunities, Threats (SWOT) dan aspek keuangan menggunakan Metode Net Present Value (NPV), Metode Internal Rate of Return (IRR) dan Metode Payback Period (PBP). Hasil penelitian pada Aspek Pasar menunjukkan Rumah Makan Krebo Jantan memiliki Strengths, Weaknesses, Opportunities dan Threats yang telah dianalisa dan diantisipasi dampak resikonya dengan baik. Pada Aspek Keuangan hasil dari Metode Net Present value (NPV) menunjukkan dana tunai yang berhasil dikumpulkan dari tahun ke tahun jika dinilai pada keadaan sekarang dengan nilai positif di akhir tahun ke 5 sebesar Rp 29.577.421,-, Metode Internal Rate of Return (IRR) menunjukkan kemampuan dari usaha perusahaan untuk memberikan nilai return / deviden rata-rata tahunan sebesar 20,494 \% dan Metode Payback Period $(P B P)$ menunjukkan kemampuan perusahaan untuk mengembalikan seluruh biaya investasi adalah selama 4 tahun 8 bulan. Berdasarkan hasil analisis finansial menunjukkan bahwa semua kriteria kelayakan secara Finansial sudah terpenuhi, sehingga pengembangan usaha layak dilaksanakan dengan kondisi yang masih normal.
\end{abstract}

Kata kunci: Kelayakan Usaha; PBP; NPV; IRR; SWOT

\begin{abstract}
Krebo Jantan Restaurant has plans to conduct business development in the field of food. Krebo Jantan Restaurant has a problem as to whether its business development plan can provide feasibility for future growth of the company. The purpose of this study is to determine the feasibility of the business plan for the development of food business with the limits of research on the assessment of market aspects \& financial aspects. Objects in interviews and questionnaires are business owners and residents around the place of business. Data on market aspects were analyzed using Strengths, Weaknesses, Opportunities, Threats (SWOT) Methods, and financial aspect using Net Present Value (NPV) Method, Internal Rate of Return (IRR) Method and Payback Period (PBP) Method. The results of the research on the Market Aspect show that Krebo Jantan Restaurant has Strengths, Weaknesses, Opportunities, and Threats that have been analyzed and anticipated the impact of the risks well. On the Financial Aspect the results of the Net Present Value (NPV) Method indicate cash collected from year to year if assessed in the present circumstances with a positive value at the end of the 5th year of Rp 29,577,421, -, the Internal Rate of Return (IRR) Method shows the ability of the company's business to provide an average annual return/dividend of $20.494 \%$ and the Payback Period (PBP) method indicates the company's ability to return all investment costs for 4 years and 8 months. Based on the results of financial analysis shows that all financial feasibility criteria are met so that business development is feasible to be carried out under normal conditions.
\end{abstract}

Keywords: Feasibility; IRR; NPV; PBP; SWOT

\begin{tabular}{lcc}
\hline Artikel masuk & $:$ & 05 Desember 2017 \\
Artikel direvisi & $:$ & 29 Desember 2017 \\
Artikel diterima & $:$ & 30 Desember 2017 \\
&
\end{tabular}

Dwiputra, Analisis Kelayakan Pengembangan Usaha Rumah Makan Krebo Jantan 


\section{PENDAHULUAN}

Pada saat ini perkembangan bisnis kuliner sudah semakin berkembang pesat. Hal ini diperlihatkan dengan banyaknya pengusaha makanan yang telah membuka usaha atau cabang baru di berbagai tempat di Indonesia dan di Cilegon khususnya

Kota Cilegon sebagai Kota Industri yang sangat besar, maka akan banyak sekali jumlah karyawan yang bekerja pada industri-industri yang ada di Cilegon. Pendapatan per kapita penduduk di Cilegon juga akan semakin meningkat dengan adanya banyak Industri di Cilegon.

Selain berkembangnya industri di daerah Cilegon, maka bidang pendidikan juga akan semakin berkembang. Jumlah siswa di Cilegon juga akan semakin banyak berkembang sesuai dengan berkembangnya industri di Cilegon. Dengan latar belakang tersebut maka Pasar kuliner Cilegon akan semakin menjanjikan dan memiliki prospek yang besar.

Pada saat ini Rumah Makan Krebo Jantan memiliki rencana untuk melakukan pengembangan usaha pada bidang makanan. Rumah Makan Krebo Jantan memiliki permasalahan tentang apakah rencana pengembangan usahanya dapat memberikan kelayakan bagi perkembangan perusahaan di masa mendatang.

Penelitian tentang kelayakan usaha telah banyak dilakukan. Penelitian pertama dilakukan oleh Latuny (2010) yang meneliti tentang bagaimana kelayakan industri kerajinan kerang mutiara dari sisi Aspek Finansial. Penelitian kedua oleh Nugroho, Bakar, \& Fitria (2014) yang meneliti tentang bagaimana kelayakan pembukaan pencucian kendaraan bermotor dilihat dari sisi Aspek Pasar, Aspek Teknis, Aspek Keuangan dan Aspek Manajemen. Penelitian ketiga dilakukan oleh Ferdiansa, Bakar, \& Fitria (2013) yang meneliti tentang bagaimana kelayakan usaha pembuatan seragam sekolah di Desa Panyirapan Soreang Kabupaten Bandung dilihat dari Aspek Pasar, Aspek Teknis, Aspek Legal dan Lingkungan, Aspek Manajemen Sumber Daya Manusia dan Aspek Finansial. Penelitian ini mencoba menilai Aspek Kelayakan Usaha dari Aspek Pasar (Analisa SWOT) dan Aspek Finansial (NPV,IRR \& PBP).

Analisis Kelayakan Aspek Pasar digunakan untuk mengetahui Aspek Pemasaran berdasarkan analisis harga, produk dan distribusi (Astanu, Ismono, \& Rosanti, 2013). Analisis kelayakan Finansial sebagai dasar untuk menentukan kelayakan suatu usaha untuk bisa dikembangkan atau tidak (Kusuma \&
Mayasti, 2014). Kesalahan dalam asumsi ketersediaan bahan baku, teknologi, tenaga kerja, biaya operasional menyebabkan potensi kegagalan bila hasil analisis dilaksanakan.

Penelitian ini bertujuan untuk mengetahui kelayakan usaha dari Aspek Pasar dan Finansial dalam pengembangan usaha Rumah Makan Krebo Jantan. Hasil penelitian bisa dijadikan rekomendasi pengembangan usaha Rumah Makan Krebo Jantan.

\section{METODE PENELITIAN}

Penelitian dilakukan pada Rumah Makan Krebo Jantan di Cilegon, Banten. Pada tahap identifikasi masalah dilakukan dengan melakukan wawancara dengan Pemilik Rumah Makan Krebo Jantan. Dengan permasalahan yang ada dilakukan studi literatur dan studi keadaan aktual dilapangan dari berbagai Aspek Pasar dan Aspek Finansial. Tahap pengumpulan data dilakukan terhadap masing - masing Aspek diantaranya Aspek Pasar : Analisis SWOT; Aspek Finansial : Analisis Investasi, Analisis Metode Net Present Value (NPV), Internal Rate of Return (IRR) dan Payback Period (PBP).

\section{Aspek Pasar}

Pengembangan usaha berhuhungan dengan pangsa Pasar pemilik usaha. Salah satu alat yang digunakan dalam pertimbangan pengembangan adalah analisis SWOT (Strengths, Weaknesses, Opportunities, Threats).

Analisis SWOT adalah alat yang digunakan untuk membantu pengambilan keputusan kelayakan usaha berdasarkan strengths, weaknesses, opportunities dan threats (Amalia, Hidayat, \& Budiatmo, 2012). Analisis SWOT berbentuk matriks yang menjelaskan faktor internal yang menjadi kekuatan dan kelemahan perusahaan dan faktor eksternal yang berupa peluang dan ancaman yang dihadapi perusahaan (Siregar, 2015). Menurut Rangkuti (2004) faktor internal yang menjadi kekuatan dan kelemahan perusahaan adalah yang berhubungan dengan Aspek sumber daya manusia, keuangan, produksi, perencanaan dan pemasaran. Faktor eksternal yang menjadi peluang dan ancaman perusahaan adalah yang berhubungan dengan pemasok, pesaing dan pelanggan.

\section{Aspek Finansial}

Aspek Finansial dilihat dari profitabilitas dan kemampuan menyediakan keuangan dengan segala konsekuensinya (Sabana, 2015). Dalam penelitian ini berfokus pada analisis investasi, Net Present Value (NPV), Internal 
Rate of Return (IRR) dan Payback Period (PBP). Analisis Investasi merupakan analisis modal yang harus dikeluarkan dengan estimasi pendapatan yang akan diterima. Net Present Value (NPV) adalah hasil selisih penerimaan dengan pengeluaran yang sudah dilakukan present value (Nufaili \& Utomo, 2014). Panjaitan, Limbong, \& Suryani (2012) mengatakan NPV adalah nilai uang sekarang yang berasal dari sejumlah uang di masa yang akan datang dan dikonversikan ke sekarang dengan memakai tingkat bunga terpilih.

$N P V=P V$ Benefit $-P V$ Cost

a. $N P V>0$, maka investasi layak secara Finansial

b. $N P V<0$, maka investasi tidak layak secara Finansial

c. $N P V=0$, maka investasi berada pada osisi titik impas (Break Event Point)

Internal Rate of Return (IRR) adalah tingkat bunga yang menggambarkan nilai bersih sekarang (NPV) sama dengan jumlah semua investasi usaha

$I R R=i_{1}+\left[\frac{N P V_{1}}{N P V_{1}-N P V_{2}}\right]\left(i_{2}-i_{1}\right)$

NPV : Net Present Value

$\mathrm{i}_{1} \quad$ : Tingkat discount rate pertama

$\mathrm{i}_{2} \quad$ : Tingkat discount rate kedua

a. IRR $>\mathrm{i}$, maka layak secara Finansial

b. $I R R<\mathrm{i}$, maka investasi tidak layak secara Finansial

c. $\quad I R R=\mathrm{i}$, maka investasi berada pada posisi titik impas (Break Event Point)

Payback Period (PBP) adalah investasi yang menjelaskan lamanya waktu yang diperlukan agar dana yang digunakan untuk berinvestasi kembali kesemuanya (Adalina, 2016). dalam penelitian ini diasumsikan lama periode waktu yang direncanakan selama 5 tahun atau 60 bulan.

$P B P=\frac{\text { Investasi Awal }}{\text { Penerimaan Periode }} \times 1$ Tahun

Usaha dikatakan layak apabila nilai PBP lebih kecil atau sama dengan umur investasi yang telah direncanakan.

\section{HASIL DAN PEMBAHASAN}

Rumah Makan Krebo Jantan dalam rencana pengembangan usaha di bidang makanan melakukan studi kelayakan dengan mempertimbangkan beberapa Aspek Pasar dan Finansial.

\section{Aspek Pasar}

Sesuai dengan data Badan Koordinasi Penanaman Modal menunjukkan bahwa adanya peningkatan jumlah realisasi investasi PMA daerah Banten dinyatakan dengan Tabel 1.

Tabel 1. Data Realisasi Investasi PMA Daerah Banten tahun 2010 - 2016

\begin{tabular}{cc}
\hline Periode & Realisasi Jumlah Proyek \\
\hline 2010 & 280 \\
2011 & 361 \\
2012 & 405 \\
2013 & 592 \\
2014 & 709 \\
2015 & 1737 \\
2016 & 2161 \\
\hline
\end{tabular}

Pasar yang menjanjikan akan semakin memberikan kemudahan dalam melakukan penjualan produk terhadap konsumen. Namun yang perlu diperhatikan dengan sudah adanya Pasar yang bagus adalah memenuhi keinginan pelanggan yang tidak bisa ditawar-tawar dan harus terpenuhi. Pelanggan tidak boleh menjadi kecewa dengan apapun pelayanan pada bidang makanan Rumah Makan Krebo Jantan.

Hal yang perlu dipertimbangkan sebelum menerapkan strategi pemasaran adalah dengan melakukan analisa SWOT (Strengths, Weaknesses, Opportunities, Threats).

Analisa Strengths (Kekuatan) dari Rumah Makan Krebo Jantan adalah :

a. Krebo Jantan memilki Chef yang handal. Dengan adanya Chef tersebut akan mampu menciptakan makanan yang lebih unggul dari para pesaing. Tentunya harus melakukan percobaan dan perbandingan dengan masakan para pesaing.

b. Krebo Jantan akan memiliki Karyawan yang sudah terlatih yakni pada bagian-bagian Produksi (Masak), Pelayanan dengan cepat dan ramah serta akan sangat terlihat profesional, serta pada bagian marketing yang dengan aktif menciptakan sebuah promosi-promosi baru yang menarik bagi pelanggan. Krebo Jantan akan melakukan pembagian tugas pada proses - proses bisnis Krebo Jantan, antara lain Pemasaran, Pembelian, Rencana Produksi \& Kontrol Persediaan, Sistem Produksi, Kontrol 
Kualitas, Gudang, Distribusi, Human Resource \& General Affair, Prosedur Kerja, Perawatan, Keuangan, Riset dan Pengembangan Produk Baru, Teknologi Informasi, Keamanan Kesehatan \& Lingkungan.

c. Tempat unik dan menarik disajikan oleh Krebo Jantan untuk dapat menambah kenyamanan dan sensasi yang berbeda pada saat menikmati menu makanan. Pemandangan yang disajikan dari lantai 2 akan dapat memberikan pengalaman berbeda bagi para pelanggan Krebo Jantan.

Analisa Kelemahan (Weaknesses)

a. Persiapan terhadap seluruh fungsi proses bisnis masih belum sempurna. Oleh karena itu perlu dilakukan persiapan sistem yang lengkap dari seluruh fungsi tersebut seperti persiapan Standar Operating Procedure (SOP).

b. Marketing Process masih perlu segera ditingkatkan. Oleh karena itu pembuatan spanduk sebagai promosi bahwa akan dibuat rumah makan Krebo Jantan akan semakin meningkatkan nilai jual dari Krebo Jantan sejak dini.

Analisa Peluang (Oppotunities)

a. Daerah Cilegon merupakan salah satu kawasan industri terbesar di Indonesia, maka tentunya akan sangat banyak profesi warga Cilegon menjadi karyawan dengan pendapatan minimal adalah UMK Cilegon yang rata-rata sebesar Rp 3.375.000,-.

b. Jenis keragaman makanan di daerah Cilegon yang masih kurang, dapat dimanfaatkan dengan membuat jenis makanan yang enak dan menarik dan tentunya menawarkan tempat makan yang menarik.

Analisa Ancaman (Threats)

Para pesaing telah banyak melakukan pembukaan tempat makan di daerah BBS Cilegon pada khususnya dan di Cilegon pada umumnya. Pesaing didaerah Cilegon contohnya adalah Labaik Chicken, Papistar, The Chick, Ayam Geprek dan Cafe dekat Mesjid. Namun hal tersebut perlu disikapi dengan terus melakukan inovasi dan pebaikan secara terus menerus dalam seluruh bidang baik menu, pelayanan dan lain-lain.

\section{Aspek Finansial}

Analisa Nilai Investasi yang dibutuhkan dalam proses pembentukan Usaha Baru Rumah Makan Krebo Jantan adalah sebagai berikut :
Tabel 2. Kebutuhan Modal Investasi

\begin{tabular}{cccccc}
\hline NO & $\begin{array}{c}\text { JENIS } \\
\text { INVESTASI }\end{array}$ & QTY & SAT & HARGA/SAT & $\begin{array}{c}\text { TOTAL } \\
\text { HARGA }\end{array}$ \\
\hline I & BANGUNAN & 1 & PAKET & 300.000 .000 & 300.000 .000 \\
II & $\begin{array}{c}\text { BARANG } \\
\text { PENDUKUNG } \\
\text { LAINNYA }\end{array}$ & 1 & PAKET & 200.000 .000 & 200.000 .000 \\
& TOTAL BIAYA & & & & 500.000 .000 \\
\hline
\end{tabular}

Tabel 3. Total Laba Rugi

\begin{tabular}{lr}
\hline \multicolumn{1}{c}{ Deskripsi } & Total \\
\hline Penjualan Per Tahun & \\
- Makanan & 630.000 .000 \\
- Minuman & 720.000 .000 \\
- Ice Cream & 135.000 .000 \\
- Makanan Lainnya & 108.000 .000 \\
Total Penjualan Per & 1.593 .000 .000 \\
Tahun & \\
Biaya Per Tahun & 18.480 .000 \\
- Marketing & 637.200 .000 \\
- Purchasing & 12.000 .000 \\
- PPIC & 60.000 .000 \\
- Packing & \\
- Pergudangan & \\
- Distribusi & \\
- SDM & 509.520 .000 \\
- Keuangan & 94.857 .143 \\
- Maintenance & 1.860 .000 \\
- Quality Assurance & 1.440 .000 \\
- Safety & 5.340 .000 \\
- Riset \& & 1.800 .000 \\
Development & 7.200 .000 \\
- Information & 1.349 .697 .143 \\
\hline Total Biaya Per Tahun & 243.302 .857 \\
\hline Total Laba Per Tahun & \\
Sebelum Pajak & \\
\hline Total Laba Per Tahun & \\
Sesudah Pajak (36 \%) & \\
\hline & \\
\hline
\end{tabular}

Perencanaan Nilai Penjualan dihitung berdasarkan pada Aspek Pasar dan juga kesanggupan dari Produksi Makanan yang dihasilkan dari Usaha Makanan Krebo Jantan dihitung per bulan dan kemudian diakumulasikan secara per tahun.

Laporan Proyeksi Laba Rugi digunakan untuk menghitung laba/ (rugi) bersih per ton dari operasional usaha makanan Krebo Jantan. Tabel 3 juga menghitung laba/ (rugi) bersih pertahun dan menghitung nilai pajak perusahaan 
yang harus dikeluarkan. Berdasarkan jumlah Laba/(Rugi) yang didapatkan oleh perusahaan sebagai konsekuensi dari proses operasional dan penjualan produk kepada konsumen. Dari perhitungan diperoleh hasil laporan Laba/(Rugi) sebesar Rp. 155.713.829.

Perhitungan Net Present Value sangat dibutuhkan untuk menghitung jumlah dana tunai dari usaha makanan yang berhasil dikumpulkan dari tahun ke tahun jika dinilai pada keadaan sekarang dengan menggunakan metoda discounted value atau faktor bunga efektif yang berlaku pada keadaan sekarang. berdasarkan hasil NPV menunjukkan jumlah dana tunai dari usaha perusahaan yang berhasil dikumpulkan dari tahun ke tahun jika dinilai pada keadaan sekarang dengan menggunakan metoda discounted value atau faktor bunga efektif yang berlaku pada keadaan sekarang. Dari cash flow diperoleh hasil Net Present Value (NPV) sebesar Rp 29.577.421.

Analisa IRR sangat dibutuhkan untuk menganalisis kelayakan Usaha Rumah Makan
Krebo Jantan sejak masa konstruksi hingga masa produksi. berdasarkan perhitungan IRR diperoleh kemampuan dari usaha perusahaan dari tahun ke tahun dalam menghasilkan dana tunai untuk memberikan nilai return/ deviden rata-rata tahunan dalam bentuk persentase terhadap dana investasi. Nilai IRR sebaiknya lebih besar dari nilai Hurdle Rate (Hurdle Rate = $10 \%)$. Dari cash flow, diperoleh hasil Internal Rate of Return (IRR) sebesar 20,499\%. (Artinya IRR $=20,494 \%>$ Hurdle Rate sebesar $10 \%$ ).

Analisa PBP sangat dibutuhkan untuk mengetahui berapa lama proyek dapat mengembalikan investasi. PBP menunjukkan kemampuan dari usaha perusahaan untuk berapa lama dapat mengembalikan seluruh biaya investasi dari dana tunai yang berhasil dikumpulkan dalam satuan waktu (tahun) dengan tidak memperhitungkan pengaruh suku bunga terhadap nilai uang. Dari cash flow, diperoleh hasil Pay Back Period sebesar 4 Tahun 8 Bulan. (Artinya PBP < Umur Ekonomis Investasi 5 Tahun)

Tabel 4. Analisa Net Present Value (NPV)

\begin{tabular}{|c|c|c|c|c|c|c|c|}
\hline TAHUN & INVESTASI & $\begin{array}{c}\text { BIAYA } \\
\text { OPERASI }\end{array}$ & TOTAL COST & BENEFIT & $\begin{array}{c}\text { NET } \\
\text { BENEFIT }\end{array}$ & $\begin{array}{c}\text { DF } 18 \\
\%\end{array}$ & $\begin{array}{l}\text { PRESENT } \\
\text { VALUE }\end{array}$ \\
\hline 0 & 500.000 .000 & & 500.000 .000 & & (500.000.000) & 1,00 & $(500.000 .000)$ \\
\hline 1 & & 1.349 .697 .143 & 1.349 .697 .143 & 1.593 .000 .000 & 155.713 .829 & 0,85 & 131.960 .872 \\
\hline 2 & & 1.417 .182 .000 & 1.417 .182 .000 & 1.672 .650 .000 & 163.499 .520 & 0,72 & 117.422 .810 \\
\hline 3 & & 1.488 .041 .100 & 1.488 .041 .100 & 1.756 .282 .500 & 171.674 .496 & 0,61 & 104.486 .398 \\
\hline 4 & & 1.562 .443 .155 & 1.562 .443 .155 & 1.844 .096 .625 & 180.258 .221 & 0,52 & 92.975 .185 \\
\hline 5 & & 1.640 .565 .313 & 1.640 .565 .313 & 1.936 .301 .456 & 189.271.132 & 0,44 & 82.732 .156 \\
\hline \multicolumn{7}{|c|}{ NPV } & 29.577 .421 \\
\hline
\end{tabular}

Tabel 5. Analisa Internal rate of Return (IRR)

\begin{tabular}{cccccc}
\hline TAHUN & NET BENEFIT & DF 18\% & $\begin{array}{c}\text { PRESENT } \\
\text { VALUE }\end{array}$ & $20,49 \%$ & $\begin{array}{c}\text { PRESENT } \\
\text { VALUE }\end{array}$ \\
\hline 0 & $(500.000 .000,00)$ & 1,0000 & $(500.000 .000,00)$ & 1,000 & $(500.000 .000,00)$ \\
1 & $155.713 .828,57$ & 0,8475 & $131.960 .871,67$ & 0,830 & $129.229 .528,92$ \\
2 & $163.499 .520,00$ & 0,7182 & $117.422 .809,54$ & 0,689 & $112.612 .250,70$ \\
3 & $171.674 .496,00$ & 0,6086 & $104.486 .398,32$ & 0,572 & $98.131 .743,69$ \\
4 & $180.258 .220,80$ & 0,5158 & $92.975 .184,94$ & 0,474 & $85.513 .246,20$ \\
5 & $189.271 .131,84$ & 0,4371 & $82.732 .156,09$ & 0,394 & $74.517 .327,42$ \\
\hline & & PV1 & $29.577 .420,56$ & PV2 & $4.096,92$ \\
\hline & & & & IRR & $20,494 \%$ \\
\hline
\end{tabular}


Tabel 6. Analisa Payback Period (PBP)

\begin{tabular}{cccccc}
\hline TAHUN & INVESTASI & NET BENEFIT & NET 18\% & PV & PBP HITUNG PV \\
\hline 0 & $500.000 .000,00$ & & 1,0000 & $(500.000 .000,00)$ & $(500.000 .000,00)$ \\
1 & & $155.713 .828,57$ & 0,8475 & $131.960 .871,67$ & $(368.039 .128,33)$ \\
2 & $163.499 .520,00$ & 0,7182 & $117.422 .809,54$ & $(250.616 .318,79)$ \\
3 & $171.674 .496,00$ & 0,6086 & $104.486 .398,32$ & $(146.129 .920,47)$ \\
4 & $180.258 .220,80$ & 0,5158 & $92.975 .184,94$ & $(53.154 .735,53)$ \\
5 & $189.271 .131,84$ & 0,4371 & $82.732 .156,09$ & $29.577 .420,56$ \\
\hline \multicolumn{5}{c}{ NPV } & \multicolumn{3}{c}{$29.577 .420,56$} \\
\hline
\end{tabular}

\section{KESIMPULAN}

Sesuai dengan Analisa SWOT yang telah dilakukan, maka dari Aspek Pasar menunjukkan bahwa Rumah Makan Krebo Jantan telah mampu memaksimalkan kekuatan (strength), dengan memiliki Chef handal, kualitas karyawan yang handal serta tempat yang nyaman. Menutupi kelemahan (weaknesses) dengan mempersiapkan seluruh bisnis proses berdasarkan SOP, dan Marketing Process perlu ditingkatkan kembali. Memanfaatkan peluang (oppurtinities) dengan memanfaatkan peluang investasi besar di daerah Cilegon dengan UMK yang besar, dan menawarkan jenis keragaman makanan terhadap pelanggan. Menangkal semua ancaman (threats) dengan menganalisa calon pesaing dan menerapkan perbaikan secara terus menerus. Berdasarkan hasil analisis Finansial menunjukkan bahwa semua kriteria kelayakan secara Finansial sudah terpenuhi, maka penanaman modal untuk pengembangan Rumah Makan Krebo Jantan adalah Layak untuk dilaksanakan dengan kondisi yang masih normal.

\section{DAFTAR PUSTAKA}

Adalina, Y. (2016). Analisis Finansial Usaha Lebah Madu Apis mellifera L. Jurnal Penelitian Hutan Dan Konservasi Alam, 5(3), 217-237.

Amalia, A., Hidayat, W., \& Budiatmo, A. (2012). Analisis Strategi Pengembangan Usaha Pada UKM Batik Semarangan di Kota Semarang. Jurnal IImu Administrassi Bisnis, 1(1), 1-12.

Astanu, D. A., Ismono, R. H., \& Rosanti, N. (2013). Analisis Kelayakan Finansial Budidaya Intensif Tanaman Pala di Kecamatan Gisting Kabupaten Tanggamus. Jurnal IImu-IImu Agribisnis, 1(3), 218-225.

Ferdiansa, F., Bakar, A., \& Fitria, L. (2013). Analisis Kelayakan Usaha Pembuatan
Seragam Sekolah di Desa Panyirapan Soreang Kabupaten Bandung. Reka Integra, 1(2), 32-43.

Kusuma, P. T. W. W., \& Mayasti, N. K. I. (2014). Analisa Kelayakan Finansial Pengembangan Usaha Produksi Komoditas Lokal: Mie Berbasis Jagung. Agritech, 34(2), 194-202.

Latuny, W. (2010). Analisis Kelayakan Aspek Finansial Industri Kerajinan Kerang Mutiara (Studi Kasus Pada UD. Mutiara Indah). Jurnal Arika, 4(1), 1105-1978.

Nufaili, R., \& Utomo, C. (2014). Analisa Investasi Hotel Pesonna Makassar. Jurnal Teknik ITS, 3(2), D143-D146.

Nugroho, I. A., Bakar, A., \& Fitria, L. (2014). Analisis Kelayakan Usaha Pencucian Kendaraan Bermotor Studi Kasus Purwokerto Timur Jawa Tengah. Reka Integra, 3(1), 27-37.

Panjaitan, J. L. U., Limbong, W. H., \& Suryani, A. (2012). Strategi Pengembangan Usaha Agroindustri Tepung Gandum di Gapoktan Gandum, Kabupaten Bandung. MANAJEMEN IKM: Jurnal Manajemen Pengembangan Industri Kecil Menengah, $7(1), 85-93$.

Rangkuti, F. (2004). Manajemen Persediaan Aplikasi di Bidang Bisnis. Jakarta: Raja Grafindo Persada.

Sabana, C. (2015). Kajian Pengembangan Produks Makanan Olahan Mangrove. Jurnal Ekonomi Dan Bisnis, 14(1), 40-46.

Siregar, G. (2015). Analisis Kelayakan dan Strategi Pengembangan Usaha Ternak Sapi Potong. Jurnal IImu Pertanian "AGRIUM," 17(3), 192-201. 